NBER WORKING PAPER SERIES

\title{
THE LONG RUN HUMAN CAPITAL AND ECONOMIC CONSEQUENCES OF HIGH-STAKES EXAMINATIONS
}

\author{
Victor Lavy \\ Avraham Ebenstein \\ Sefi Roth \\ Working Paper 20647 \\ http://www.nber.org/papers/w20647 \\ NATIONAL BUREAU OF ECONOMIC RESEARCH \\ 1050 Massachusetts Avenue \\ Cambridge, MA 02138 \\ October 2014
}

Excellent research assistance was provided by Eyal Frank, Michael Freedman, Michal Hodor, Susan Schwartz, and Ben Raven. We thank Josh Angrist, Andrea Ichino, Sascha Becker, Eric Maurin, Erik Plug, Fabian Waldinger, seminar participants at Hebrew University, University of London Royal Holloway, RES annual meeting 2014, and CAGE May 2014 conference on Education, Human Capital and Labor Market Outcomes for useful comments and suggestions. We thank Israel's National Insurance Institute (NII) for allowing restricted access to data in the NII protected research lab. Research of the first author is supported by European Research Council (ERC) Advance Grant No. 323439. The views expressed herein are those of the authors and do not necessarily reflect the views of the National Bureau of Economic Research.

NBER working papers are circulated for discussion and comment purposes. They have not been peerreviewed or been subject to the review by the NBER Board of Directors that accompanies official NBER publications.

(C) 2014 by Victor Lavy, Avraham Ebenstein, and Sefi Roth. All rights reserved. Short sections of text, not to exceed two paragraphs, may be quoted without explicit permission provided that full credit, including (C) notice, is given to the source. 
The Long Run Human Capital and Economic Consequences of High-Stakes Examinations Victor Lavy, Avraham Ebenstein, and Sefi Roth

NBER Working Paper No. 20647

October 2014

JEL No. I21,I26,J24

\begin{abstract}
$\underline{\text { ABSTRACT }}$
Cognitive performance during high-stakes exams can be affected by random disturbances that, even if transitory, may have permanent consequences for long-term schooling attainment and labor market outcomes. We evaluate this hypothesis among Israeli high school students who took a series of high stakes matriculation exams between 2000 and 2002. As a source of random (transitory) shocks to highstakes matriculation test scores, we use exposure to ambient air pollution during the day of the exam. First, we document a significant and negative relationship between average $\mathrm{PM}_{2.5}$ exposure during exams and student composite scores, post-secondary educational attainment, and earnings during adulthood. Second, using $\mathrm{PM}_{2.5}$ as an instrument, we estimate a large economic return to each point on the exam and each additional year of post-secondary education. Third, we examine the return to exam scores and schooling across sub-populations, and find the largest effects among boys, better students, and children from higher socio-economic backgrounds. The results suggest that random disturbances during high-stakes examinations can have long-term consequences for schooling and labor market outcomes, while also highlighting the drawbacks of using high-stakes examinations in university admissions.
\end{abstract}

Victor Lavy

Department of Economics

University of Warwick

Coventry, CV4 7AL

United Kingdom

and Hebrew University of Jerusalem

and also NBER

v.lavy@warwick.ac.uk

Avraham Ebenstein

Department of Economics

Hebrew University of Jerusalem

Mount Scopus Campus, \#4208

Jerusalem, Israel 91905

ebenstein@mscc.huji.ac.il
Sefi Roth

Department of Economics

Royal Holloway

University of London

Egham TW20 0EX

United Kingdom

s.j.roth@rhul.ac.uk 


\section{Introduction}

Cognitive performance is critical to scholastic achievement and to successful performance in many occupations. Cognitive acuity can be affected temporarily by a variety of factors, including the intake of caffeine, nicotine, and sleep deprivation (Jarvis 1993, Angus, Heslegrave and Myles 1985). Factors that induce variation in the cognitive performance of students during high-stakes exams may be of particular interest because they potentially affect long-term schooling attainment, and therefore can have permanent effects on wages and earnings. In this paper, we examine the potential long-term effect of transitory disturbances to cognitive performance during high-stakes exit exams in Israeli high schools. The exams are known as a the Bagrut and are a critical component of Israel's college admissions system, acting as a gatekeeper for the most selective schools, similar to the role played by Scholastic Aptitude Tests in the United States or A-levels in England and other European countries. Access to college majors is also determined by Bagrut performance, with many lucrative professional programs requiring minimum overall average scores for admission, such as law and medicine. As a consequence, Bagrut scores can affect an individual's entire academic career, and subsequent labor market outcomes.

Although many countries use high-stakes testing to rank students for college admission, the consequences of this policy are largely unknown. Does having a particularly good or bad performance on a high-stakes examination have long-term consequences for test takers, after accounting for a student's cognitive ability? Insofar as there are permanent wage consequences to variation induced by completely random shocks to student performance on a test like the Bagrut, it suggests that the use of high-stakes testing as a primary method for ranking students may be inefficient. Aggregate welfare may also be reduced by relying too heavily on examinations that provide noisy measures of student quality, since it may lead to poor matching between students and occupations, and an inefficient allocation of labor. Recent debate over the planned redesign of the SATs has been in part motivated by concerns that the current version is highly 
random and does not represent a fair measure of student quality (New York Times 2014). ${ }^{1}$ In spite of a dearth of evidence regarding the consequences of these tests, they are used extensively globally to rank students and allocate opportunity by acting as a gatekeeper in admissions.

Assessing the consequences of using high-stakes examinations for ranking students is challenging. First, large data samples are generally not available with standardized test scores and wages during adulthood for a representative population. ${ }^{2}$ Second, since higher-ability students presumably perform better on high-stakes tests, it is difficult to separately distinguish the return to cognitive ability from the return to doing well on the examination. One possible solution is to examine the consequences of fluctuations in a random component affecting performance on these tests. A candidate is fluctuation in air pollution that might have an effect on cognitive acuity and test scores, therefore generating plausibly random variation in a given student's outcome. Air pollution has been demonstrated to adversely affect human productivity across a variety of tasks (Graff Zivin and Neidell 2012, Chang et al. 2014). Since students are assigned to test sites without prior knowledge of pollution or the ability to reschedule, it represents an exogenous factor affecting performance. This may enable direct measurement of the return to the component of a student's score which is related entirely to luck, and provide evidence regarding whether these tests do or do not have long-term consequences.

In this paper, we examine the long-term consequences of high-stakes examinations using exogenous variation in scores generated by pollution exposure. We examine student performance on the Bagrut, a series of examinations across different subjects that Israeli students must pass as a prerequisite for entry into elite universities. The analysis presented here builds on earlier work where we estimated the reduced form causal impact of various pollutants on cognitive performance (Lavy et al. 2013). In

\footnotetext{
${ }^{1}$ In a recent discussion of the planned revisions to the SATs, the president of the College Board stated that "only 20 percent...see the college-admission tests as a fair measure of the work their students have done." (New York Times 2014)

${ }^{2}$ Note that in the United States, Educational Testing Service (ETS) is notoriously private and no scholarship (to our knowledge) has been carried out linking SAT scores to adult outcomes for even small subsets of the population. For military recruits, the ASVAB has been made available but it is unclear how relevant this is for other sub-populations (Cawley et al. 2001).
} 
Lavy et al. (2013), we exploit exam-level data to demonstrate that pollution harms student performance, even in models with student-fixed effects where we exploit variation in pollution across test administrations for the same student. We find significant effects of particulate matter $\left(\mathrm{PM}_{2.5}\right)$ and carbon monoxide (CO) on student performance, and demonstrate in a set of placebo exercises that the effects are very short-term: no significant effect is found of pollution on days before or after the exam. In this paper, we focus more narrowly on fine particulate matter $\left(\mathrm{PM}_{2.5}\right)$, considered to be particularly harmful to human health and cognition, and use it as an instrumental variable for a student's average Bagrut score across the series of examinations. Since Israel has frequent sandstorms, we are able to exploit severe short-term pollution which generates a first-stage relationship between pollution exposure and a student's Bagrut scores. ${ }^{3}$ Another feature that makes Israel a suitable context for answering this research question is data availability. Israel's national registration system allows us to match the universe of students who take the Bagrut with their completed post-high school education and their wages in adulthood, enabling us to examine the impact of these tests in the long run for every test taker.

In the first part of our analysis, we examine the relationship between average pollution exposure during the Bagrut exams and long-term academic and economic outcomes. We exploit variation across students at the same school in their average pollution exposure, which stems from differences in the exam dates across different subjects. The identification assumption is that variation across students from the same school in the dates of Bagrut exams is not correlated with potential outcomes, which is a plausible assumption because dates of national Bagrut exams are determined by the Ministry of Education, and students choose their Bagrut study program years before the dates of exams are determined. ${ }^{4}$ Using this

\footnotetext{
${ }^{3}$ We note here that most of the Southern and central European countries, even England, are seriously affected by the same sand storms that originate from the Sahara. See for example media coverage of early April 2014 episodes of extremely high pollution levels in this region at: http://www.bbc.com/news/uk-26844425.

${ }^{4}$ In support of this assumption, we provide the results of balancing tests that demonstrate that pollution does not appear to be correlated with observable features of the student, after conditioning on the student's school. As additional support for our approach, we cite evidence presented in Lavy, Ebenstein and Roth (2013) where we use exam-level data to estimate the effect of pollution on test scores, allowing us to simultaneously control for time-invariant features of localities, schools and individual students. We present evidence that the results are broadly similar with student fixed effects or school fixed effects, supporting our identification strategy.
} 
design, we present evidence that completely random variation in Bagrut scores has a long term impact on both academic and economic outcomes. We estimate that an additional 10 units of $\mathrm{PM}_{2.5}$ (AQI) in average exposure is associated with a $.023 \%$ decline in a student's Bagrut composite score, a $0.03 \%$ percent decline in Bagrut matriculation certification, a .019\% decline in enrollment in post-secondary education, and a 0.15 decline in years of education at a university. The wage consequences are also significant, with an additional 10 units of $\mathrm{PM}_{2.5}$ in average pollution exposure lowering monthly income by 109 Israeli shekel (\$29), roughly a $2 \%$ decline. This suggests that students who take an exam during a severe pollution episode experience non-trivial long run consequences, both academically and economically.

We then exploit the strong first-stage relationship between average pollution exposure during Bagrut exams and Bagrut composite scores to estimate the economic return to each additional point on the Bagrut. Using 2SLS, we estimate that each point is worth (in 2010) 66 shekels (\$18) in additional monthly earnings. Since the standard deviation on Bagrut composite scores is roughly 24 points, this implies that there are significant wage consequences to the exam, even for relatively small deviations in one's score. We examine mechanisms for this result by examining our other academic outcomes, treating the Bagrut composite score as the endogenous regressor and using pollution as our instrument. We find that each additional instrumented point increases the probability of receiving a matriculation certificate by 2 percentage points, enrollment rates in post-secondary academic schooling by 1.9 percentage points, and post-secondary education by .092 years. This suggests that the mechanism for the Bagrut's impact on student outcomes is through the posited channel of affecting a student's prospects for post-secondary education.

In light of the strong relationship between Bagrut pollution exposure and post-secondary education, we are able to use 2SLS to estimate the implied return to education. We estimate that an additional postsecondary year of schooling is worth 707 shekels (\$191) per month, an implied return to college education of $14 \%$. This rate is only marginally higher relative to existing estimates found in Israel and elsewhere for the return to post-secondary education (Frish 2009, Oreopoulos and Petronijevic 2013, Angrist and Chen 
2011, Angrist and Lavy 2013). ${ }^{5}$ As we discuss, the exclusion restriction may be violated in this context, but the similarity of our estimates to existing estimates of the return to post-secondary education is supporting evidence that the magnitude of our estimated effects of $\mathrm{PM}_{2.5}$ on schooling and economic outcomes are reasonable. ${ }^{6}$

In the last section, we examine the heterogeneity of pollution's effect on scores and wages across sub-populations in Israel. We find that our first-stage relationship is strongest among populations of Israel which have the highest rates of asthma, suggesting a physiological mechanism for the observed relationship between pollution and exam outcomes. Our estimated effects are four times larger for boys than girls, twice as large for weaker students relative to stronger students, and a fifth larger for students from lower SES relative to students from high SES background. We then examine the impact of pollution on long run outcomes for these groups. We estimate that a point on the Bagrut is worth more for boys than girls (78 shekels versus 59 shekels), for stronger students than weaker students (124 shekels versus 80 shekels), and for higher SES students relative to lower SES students (105 shekels versus 56 shekels). These magnitudes suggest that the return to an extra point is quite substantial, especially for already-strong students or students from privileged backgrounds, who presumably can capitalize on the opportunity of gaining admission to a longer academic programs or professions that require long (and poorly paid) internships, like law or medicine.

Our analysis highlights a major drawback of using high-stakes examinations to rank students. If completely random variation in scores can still matter ten years after a student completes high school, this suggests that placing too much weight on high-stakes exams like the Bagrut may not be consistent with meritocratic principles. A second implication of this finding is that by temporarily lowering the productivity of human capital, high pollution levels lead to allocative inefficiency as students with higher human capital

\footnotetext{
${ }^{5}$ For example, Angrist and Lavy (2009) estimate that Bagrut holders earn 13 percent more than other individuals with exactly 12 years of schooling.

${ }^{6}$ Since the Bagrut composite score directly affects the post-secondary education options available to a student, 2SLS models of the return to post-secondary education using pollution as an instrument will be biased by the omission of the Bagrut composite score.
} 
may be assigned a lower rank than their less qualified peers. This may lead to inefficient allocation of workers across occupations, and possibly a less productive workforce. The results highlight the danger in assigning too much weight to a student's performance on a high-stakes exam, rather than their overall academic record. Our results also contribute to existing evidence that transitory random shocks that are unrelated to levels of human capital can have long-term implications for earnings (Oreopoulos et al. 2012). Our study also highlights the role of luck in determining wages, a pattern noted by other scholars (Bertrand and Mulinathan 2001).

The rest of the paper is laid out as follows. In the second section, we present relevant background information on air pollution and cognition, and on the controversial use of high-stakes examinations in college admissions both in Israel and abroad. In Section III, we present our empirical results for the overall sample and examine heterogeneity in the results across sub-populations in Section IV. We conclude in Section V.

\section{Background and Data}

\section{A. Air pollution and Cognitive Performance}

The existing literature provides compelling evidence that cognition may be affected by pollution, as a result of pollution's effect on the respiratory system. Researchers have documented that short-term acute exposure to particulate matter leads to increased risk of illness including heart disease, stroke, and lung cancer, in addition to increased hospitalization rates (Pope et al. 1995, Dockery and Pope 1996; Schlenker and Walker 2011, Chay and Greenstone 2003). Exposure to fine particulate matter is particularly dangerous since these small particles penetrate deep in to the lungs effecting blood flow and oxygen circulation, which may also affect other aspects of human life, and in particular, cognition (Pope and Dockery 2006). Since the brain consumes a large fraction of the body's oxygen needs, any deterioration in oxygen quality can in theory affect cognition (Clark and Sokoloff 1999, Calderón-Garcidueñas et al. 2008). Air pollution can also impact the nervous system, leading to symptoms such as memory disturbance, fatigue and blurred vision (Kampa and Castanas 2007). As a result of these physiological effects, a recent literature 
has been able to document that pollution significantly lowers labor productivity in a variety of contexts (Graff Zivin and Neidell 2012, Chang et al. 2014).

In a related paper (Lavy, Ebenstein and Roth, 2013), we examine the effect of pollution on cognition in the Israeli context, examining the relationship between test scores and exposure to particulate matter and carbon monoxide. We analyze the impact of pollution in a panel data set where we observe the same student taking multiple exams with different levels of pollution on each day, enabling us to estimate models with student fixed effects. For particulate matter exposure, we find that a one standard deviation increase in the $\mathrm{PM}_{2.5}$ AQI value ( $\left.\mathrm{sd}=22.81\right)$ on the day of an exam is associated with a .65 point decrease in score, or $2.8 \%$ of a standard deviation. ${ }^{7}$ We also find that our results are largely driven by poor performance of test takers on extremely polluted days, with an AQI reading above 101 for $\mathrm{PM}_{2.5}$ associated with a decline in test score of 1.95 points, or $8.2 \%$ of a standard deviation. These results suggest that modest pollution levels have only a marginal impact, but extremely polluted days can have much larger impacts, suggesting a non-linearity in pollution's relationship with cognitive performance.

In this paper, we focus our attention exclusively on particulate matter $\left(\mathrm{PM}_{2.5}\right)$ : a complex mixture of solid and liquid microscopic droplets found in the air that consists of various components including acids, metals, dust particles, organic chemicals and allergens. This is a natural choice since it is arguably the most harmful pollutant for human health, and presumably most likely to affect cognition. We also focus on student-level data instead of exam-level data, since our interest here is understanding how a particular student is affected by variation in their composite Bagrut score, which has more relevance for understanding the long-term consequences of the exam.

\section{B. High-Stakes Examinations in Israel and Abroad}

Since the Scholastic Aptitude Test's (SAT) first administration in 1926, it has been taken by millions of test-takers and has been used to rank students applying for college in the United States, and

\footnotetext{
${ }^{7}$ We find the effect is concentrated on the day of the exam, with insignificant effects on the day before and day after the exam. Results can be found in Ebenstein, Lavy, and Roth (2013).
} 
similar tests are used around the globe. However, the use of these tests is extremely controversial. Numerous concerns have been voiced by both popular and academic sources, including allegations of racial bias, arguments that test prep courses give privileged students an unfair advantage, and suggestions that the test places too much emotional stress on students. ${ }^{8}$ Nevertheless, the SAT remains a critical component of college admissions in the US and, just as the Bagrut does in the Israeli educational system. The great weight placed on an exam given on one particular day has the benefit of being a cost-effective way of comparing students across schools with a similar metric, but may also represent a noisy measure of student quality. Many factors can affect student performance that are unrelated to cognitive ability, including how a student slept the previous night, whether the testing room has a comfortable temperature, and potentially, exposure to ambient air pollution. In light of the great weight placed on test scores in admissions processes at many elite schools, it is worth knowing whether (a) these scores are sensitive to random shocks and (b) whether bad draws have long-run consequences. Since this would be an extremely challenging question to address in the US, where SAT score data is fiercely guarded and generally not available for matching to adult outcomes, the Israeli Bagrut represents a novel opportunity to examine this question.

All universities and most academic and teachers' colleges require a Bagrut certificate for enrollment, while entry requirements for other post-secondary education establishments, such as academic colleges, are lower. ${ }^{9}$ For a given field of study, it is typically more difficult to be admitted to a university than to an academic college, since universities are both more prestigious and more heavily subsidized by the government. Students earn a Bagrut certificate by passing a series of national exams (Bagrut tests) in core and elective subjects following tenth and eleventh grade, and then passing a larger set of exams

\footnotetext{
${ }^{8}$ In 2001, the President of University of California famously threatened to remove the SAT requirement for admission, leading to a re-design of the examination and the introduction of a writing section. However, the writing section later came under fire for rewarding students simply for lengthy essays (Winerip 2005).

${ }^{9}$ The post-secondary education system in Israel consist of eight universities that grant PhDs (as well as other degrees), approximately 50 academic colleges which offer undergraduate degrees (of which a very limited subset which offer masters degrees), and a set of non-university institutions of higher education that confer teaching and vocational certificates. Practical engineering colleges run two-year programs awarding degrees (or certificates) in fields like electronics, computers, and industrial production. An additional two years of study in an engineering school is required in order to complete a BSc in engineering.
} 
following twelfth grade. The exam focuses on seven mandatory subjects and one or more elective subjects, allowing us to observe students completing exams with separate grades for each examination and over a range of subjects. About 52 percent of high-school graduates in 2002 and 46 percent of the overall cohort received matriculation certificates, a figure that is publicized in the national media in light of the great significance of passing the Bagrut in the Israeli educational system

Students are admitted to university programs on the basis of their average Bagrut scores and a separate psychometric examination. Each university ranks applicants according to the same formula, thus producing an index based on a weighted average of the student's average score on all his or her Bagrut exams and the psychometric examination. This ranking determines students' eligibility for university admission, and even which major they can choose within the university. Therefore, pollution levels can affect students' university schooling by affecting their probability of passing Bagrut exams, and also by affecting the average score in these exams. The first channel will affect eligibility for university admission while the second will affect which programs (or majors) will be available to the student.

\section{Evaluating the Consequences of High-Stakes Examinations}

\section{A. Data}

Our data set is generated by combining Israeli test score data with air pollution and meteorological data for 2000-2002, and subsequent higher education and earnings outcomes from 2010-2011. The Bagrut exam information and demographic information for each test taker are provided by the Israeli Ministry of Education. These files also contain rich demographic information on the student and the student's family, such as parental education level, number of siblings, country of origin, and ethnicity. For each exam, we also know the exact date of the test and the precise location of the testing site, allowing us to assign pollution measures to each test administration. Our pollution data are taken from files published by the Israeli Ministry of Environmental Protection, which reports daily mean readings of particular matter less than 2.5 microns in width, or $\mathrm{PM}_{2.5}\left(\mu \mathrm{g} / \mathrm{m}^{3}\right)$ at 139 monitoring stations throughout Israel for the sample period (see Figure 1). Readings are taken at 5 minute intervals and averaged over the course of the day. Each test site, 
which is at the student's school, is assigned the average pollution reading for all monitoring stations within 2.5 kilometers of the city limits of the school. Since Israeli cities are not very large, we generally are taking readings from stations very close to the schools. While we ideally would have a measure of pollution inside the test room, the air quality inside a test site is presumed to be highly correlated with the ambient reading outdoors (Branis et al. 2005). Schools that had no monitoring station within the city limits or 2.5 kilometers of the city limits were dropped from the sample. ${ }^{10}$ These monitoring stations also record temperature and relative humidity, which are also assigned in a similar manner to pollution and are used as control variables. We use the daily average reading of pollution, temperature, and humidity at the monitoring stations in our analysis. The pollution measure is then converted into units of Air Quality Index (AQI) using a formula specified by the US EPA.

Our information on post-secondary enrollment and earnings is taken from administrative records provided by the National Insurance Institute of Israel (NII). In order to facilitate the analysis presented here, the NII Research and Planning Division constructed an extract containing indicators of post-secondary enrollment, the number of years of post-secondary schooling, annual earnings, and number of months employed among all individuals in our study. This file was then merged with our original sample and analyzed at a secure research lab at the NII headquarters in Jerusalem, Israel. Our administrative sample includes information for each student on whether they have ever enrolled in higher education for each of the aforementioned institution types, and the number of years they were enrolled in higher education by institution type. This information is available for all students, and is recorded as of the 2010-2011 academic year. The youngest cohorts in our sample are already 28 years old at this time, implying that even after accounting for compulsory military service, most students who enrolled in post-secondary education, including those who continued on to graduate school, will have graduated by $2010-2011 .^{11}$

\footnotetext{
${ }^{10}$ Since Israel's population is densely concentrated in several metropolitan areas, this led to the dropping of less than $5 \%$ of schools.

${ }^{11}$ Boys serve for three years in the military and girls for two (longer if they take a commission).
} 
The summary statistics for our sample are presented in Table 1 in two panels; Panel A reports sample means of our exam-level data, and Panel B reports sample means of our student-level data. The sample is composed of 415,219 examinations taken by 55,873 students at 712 schools throughout Israel. In columns (2) and (3) we stratify the sample by sex, and in columns (4) and (5), we stratify by a measure of achievement known as the Magen score. The Magen score is calculated using the student's performance over the course of the school-year, and on exam similar to the Bagrut, making it a natural candidate for stratifying the sample by student quality. ${ }^{12}$ As shown in Table 1, for each Bagrut examination we observe the exam score, the pollution the day of the exam $\left(\mathrm{PM}_{2.5}\right)$, and the average temperature and humidity that day. ${ }^{13}$ The table reveals that students face average pollution levels (AQI) that appear balanced along observables, with similar average readings among boys and girls (59.5 versus 59.9), and among higher/lower achievement students (60.0 versus 59.5). The sample means also reflect that girls perform better than boys, and student with higher Magen scores also have higher Bagrut scores.

In Panel B, we report our student-level means, which includes demographic information on the student, the education of both parents, and the student's earnings in 2010. Since our analysis of long-term economic outcomes will rely on school fixed effects, it is particularly important that we are able to include this rich set of control variables. The sample means also reveal several interesting patterns, including the higher achievement of girls: roughly $71 \%$ of girls receive a matriculation certificate, compared to only $64 \%$ of boys. Interestingly, however, girls earn lower earnings than their male counterparts. Boys earn on average 5,531 New Israeli Shekels (NIS) versus 4,699 for girls (\$1 3.75NIS). In columns (4) and (5), we observe higher rates of matriculation certification (91\% versus $48 \%)$ and wages $(5,352$ versus 4,867$)$ in the group of high achievement students, consistent with our expectations. Almost two thirds (63\%) of a high school cohort are enrolled in post-secondary studies, $27 \%$ in universities, and $25 \%$ in academic colleges. The sample also reveals that we are able to match the entire universe of student test takers with their long-term outcomes, a particularly desirable feature of our data relative to panel data sets that face attrition.

\footnotetext{
12 The date on which the Magen exam is given is unavailable, precluding a direct analysis of these scores.

13 These variables are not shown due to space considerations but are used in regressions available in the appendix.
} 


\section{B. Empirical Strategy}

Our analysis focuses on student-level data, where we exploit variation across students in their average level of pollution across all their Bagrut tests. In this setup, the endogenous regressor is the student's Bagrut composite score, which is calculated as the average score across the Bagrut examinations. The identification assumption in the 2SLS analysis is that variation in the timing of Bagrut exams is not correlated with potential outcomes, after conditioning on a student's school. This is a plausible assumption because dates of national Bagrut exams are determined by the Ministry of Education, and students choose their Bagrut study program years before the dates of exams are determined. The realization of pollution level on different exam dates is random, and therefore variation in average pollution exposure is also random. In support of this assumption, we provide balancing estimates that demonstrate that, conditioned on locality or school, pollution does not appear to be correlated with observable features of the student.

A likely possibility is that pollution is correlated with time invariant features of a testing location or a particular student. For example, if poorer schools are located in more polluted parts of cities, OLS will likely overstate the causal link between pollution and test scores. Conversely, if schools in denser (and wealthier) cities have more pollution exposure, OLS might understate the true cost of pollution, as it is mitigated by other compensating factors (e.g. tutoring). More generally, endogenous sorting across schools, heterogeneity in avoidance behavior, or measurement error in assigning pollution exposure to individuals will all bias results that do not properly account for unobserved factors correlated with both our outcome of interest and ambient pollution (Moretti and Neidell 2011). In our setup, since we account for timeinvariant features of schools and students with fixed effects, the challenge relevant to our estimation is to account for omitted variables that are varying over time but are potentially correlated with pollution and Bagrut scores. For example, if weather or traffic the day of the exam is correlated with pollution, our fixed effects models will fail to identify the true effect. In our empirical analysis, we include controls for timevarying factors that could be contemporaneous with pollution, such as daily temperature and relative humidity, but of course it is untestable whether there are factors that are unobserved that are both correlated with pollution and Bagrut exam scores. In Lavy et al. (2013), we conduct a rich set of robustness checks 
and placebo tests documenting the impact of pollution on test performance. ${ }^{14}$ In this paper, we are interested in exploiting this relationship to examine the consequences of high-stakes exams.

Our estimation strategy is relatively straightforward. We estimate models relating the average air quality conditions during the examination to the student's composite score. Formally, the first stage model that we estimate is of the following form:

(1) $R_{i s}=\beta_{0} X_{i s}+\beta_{1} \overline{P O L}_{i s}+\beta_{2} \overline{T e m p}_{i s}+\beta_{3} \overline{R H}_{i s}+S_{s}+\varepsilon_{i s}$

where $R_{i s}$ is the Bagrut composite test score of student $i$ at school $s ; ; \quad X_{i t}$ is a vector of individual characteristics possibly related to test outcomes, such as parental education: $\overline{P O L}_{\text {is }}$ is average air pollution exposure of student $i$ at school $s$ across the examinations; $\overline{\text { Temp }}_{\text {is }}$ is the mean temperature for student $i$ at school $s$ across the examinations; $\overline{R H}_{\text {is }}$ is the average humidity measure of student $i$ at school $s$ across the examinations; $S_{s}$ and ${ }_{i s t}$ is an idiosyncratic error term. The second stage equation is as follows:

(2) $O_{i s}=\gamma_{0} X_{i s}+\gamma_{1} \hat{R}_{i s}+\gamma_{2} \overline{T e m p}_{i s}+\gamma_{3} \overline{R H}_{i s}+S_{s}+\varepsilon_{i s}$

where $O_{i s}$ are the other long-term outcomes: Bagrut matriculation, post-secondary enrollment, postsecondary years of schooling, and monthly earnings, all measured at age 30 and $S_{s}$ is a school-fixed effect.

\section{Estimates of Pollution's Impact on Long-Term Outcomes}

In this section, we first examine the reduced form relationship between average $\mathrm{PM}_{2.5}$ exposure during the Bagrut exams and long-term outcomes. For identification we rely on variation in average pollution exposure across students within school which is driven by the timing of different exams across different subject areas. As previously discussed, this is unlikely to be correlated with student potential outcomes. We empirically support this in balancing exercises presented in Table A1, where we demonstrate

\footnotetext{
${ }^{14}$ In Lavy et al. (2013), we estimate models with higher order polynomial functions of temperature. The results are very similar, which is logical, since most classrooms where the exams are held have air conditioners.
} 
that, conditioned on city or school, pollution does not appear to be correlated with observable features of the student. We find that the balancing coefficients estimates are of small magnitude and not significantly different than zero. As further evidence in support of our identification strategy, we also note that in results presented in Lavy et al. (2013), the estimated effect of pollution was not systematically sensitive to adding student fixed effects, suggesting that our results are robust to the type of fixed effects included.

In Table 2, we present the reduced form effect of average $\mathrm{PM}_{2.5}$ on four academic outcomes related to the Bagrut. In the first two rows, we report the outcomes most directly related to performance on the Bagrut: the composite score and receiving a matriculation certificate. Receiving a matriculation certificate is of paramount importance, since this is a prerequisite for post-secondary college and university studies. However, the Bagrut composite score can also influence the range of programs accessible to a student. As highlighted in the table, both exhibit a robust negative relationship with air quality. An additional 100 units of $\mathrm{PM}_{2.5}$ (AQI) is associated with a 16.4 reduction in a student's composite score and a $.33 \%$ decline in certification in our preferred estimation strategy which include school fixed effects. ${ }^{15}$

In rows 3 and 4, we present the estimated effect of average pollution exposure on two longitudinal educational outcomes: enrollment in post-secondary institution (1=yes), and years of post-secondary schooling attained. The results demonstrate that these academic outcomes are affected by pollution exposure. In particular, enrollment rates in higher education decline by $.30 \%$ when a student is exposed to an additional 100 units of $\mathrm{PM}_{2.5}$, schooling declines by .15 years. All estimates are statistically significant at the 5\% level, and suggest that taking Bagrut exams in highly polluted days can have long-lasting effects on schooling attainment. In the fifth row, we present the reduced form effect of average $\mathrm{PM}_{2.5}$ on average monthly earnings. In our preferred specification with school fixed effects in column 3 , we estimate that a student exposed during the Bagrut exams dates to an additional 100 units of $\mathrm{PM}_{2.5}$ is associated with an

\footnotetext{
${ }^{15} \mathrm{We}$ also estimated the reduced form effect of pollution on the number of exams a student failed and on the proportion of failed exams. We find that higher $\mathrm{PM}_{2.5}$ exposure is associated with an increased chance of failing an exam in models with student fixed effects, and increases the proportion of failed exams in models with school fixed effects. This evidence is available from the authors upon request.
} 
average monthly earnings decline at age 28 of 1,093 shekels (\$291). This estimate is also precisely estimated, with a T statistic greater than three.

As a summary of the reduced form effects, we note that a one standard deviation $(\mathrm{sd}=16.7)$ change in average air quality is associated with the following effects: a decrease in average test scores by $0.10 \mathrm{sd}$ (16.8), average matriculation rates by $0.11 \mathrm{sd}(0.48)$, average years of post-secondary schooling by $0.11 \mathrm{sd}$ (2.2) and in average monthly earnings by $0.033 \mathrm{sd}$ (IS 4,515).

\section{The Long-Term Consequences of the Bagrut}

In Table 3, we use as a first-stage relationship the highly significant reduced form effect of pollution on a student's Bagrut composite score to examine the long-term consequences of the examination. In Panel A, we estimate the return to an additional point on the Bagrut composite score using 2SLS. In the first row, we reproduce the relationship between the Bagrut composite score and $\mathrm{PM}_{2.5}$ shown in Table 2 that is used here as our first-stage. Exploiting the relationship between scores and pollution, we find using 2SLS that an additional point is worth 45 shekels in monthly earnings in models with city fixed effects, and 66 shekels in our preferred specification including school fixed effects. Since the standard deviation of the Bagrut composite score is roughly 17 points, these estimates imply that even small deviations from a student's "average" score can have significant consequences on adult income.

In Panel B, we use the first-stage relationship between pollution and the Bagrut composite score to examine the mechanisms underlying the strong relationship between scores and earnings. Since the Bagrut composite score is an important factor in gaining admission into lucrative courses of study, it is logical to examine whether the instrumented score is correlated with subsequent educational outcomes. As shown in Panel B, we find that each additional instrumented point increases the probability of receiving a matriculation certificate by 2 percentage points, enrollment rates in post-secondary schooling by 1.9 percentage points, and post-secondary educational attainment by .092 years. This indicates that an additional Bagrut point has a tremendous economic value to a student, and even random variation in scores can have important consequences for a student's future attainment of post-secondary schooling. 
In Panel C, we exploit the relationship between pollution exposure and the Bagrut composite score to estimate the return to an additional year of post-secondary schooling. It is worth noting that this strategy does not identify 'cleanly' the rate of return to schooling since the Bagrut score can directly affect earnings, and therefore its omission might violate the exclusion restriction. However, as way of benchmarking our results, we wish to compute the return to education and compare our estimates to those found in the existing literature. Treating post-secondary schooling as the endogenous regressor and $\mathrm{PM}_{2.5}$ as the instrument, we estimate using 2SLS that each additional year of post-secondary schooling is worth 707 (\$191) shekels. This estimate implies that a one sd (16.7) change in average air quality changes average monthly earnings by $0.1 \mathrm{sd}$ (16.8). Relative to the average monthly earnings of 5,084 shekels $(\$ 1,374)$ in our sample of young adults, this means that fortunate students who have less pollution on their Bagrut exams dates will have long-term economic benefits to their good luck. This estimate implies a rate of return to college education of $14 \%$, which is somewhat higher in comparison with recent estimates in Israel and elsewhere. For example, Angrist and Chen exploit variation in veteran status and the GI Bill to estimate a return to education of roughly 9\% (Angrist and Chen 2011).

While our IV approach will not be valid if pollution exposure on exam dates leads to a permanent diminution of intellectual ability, in light of the highly temporary nature of pollution in Israel, such as sandstorms, we think it is unlikely that our effects are picking up such an effect. In Lavy et al. (2013), we present evidence that exposure to pollution in our data is only related to temporary variation in performance. We find that a student's average pollution exposure during the Bagrut period (May-July) in $11^{\text {th }}$ grade has no correlation with his or her average Bagrut scores on exams taken in May-July of $12^{\text {th }}$ grade, suggesting that the effects we estimate are capturing the consequences of short-term random shocks, rather than reflecting long-term cognitive diminution.

We examine possible mechanisms for our results by examining how pollution affects the probability of a student matriculating at different types of post-secondary institutions. If our results are operating through a mechanism in which the Bagrut is a gatekeeper to lucrative occupations, we should find that our results are driven by large estimated effects for universities, and milder effects for academic 
colleges. In fact, it may be that for students who attend technical schools, there is no financial value to passing the Bagrut, insofar as they purse a profession of a technical nature. This could similarly be true for students planning to be small business managers, which is common in Israel, especially among the IsraeliArab population, who generally have more limited access to lucrative professions. ${ }^{16}$ As reported in Table A3, this is indeed the case, with our effects significant and negative only for the probability of attending a university. In fact, interestingly, the impact of pollution is positive (though imprecisely measured) for the less competitive programs, such as teacher's colleges and semi-engineering programs, possibly due to students being shifted out of universities or academic colleges and into these less selective programs.

\section{Heterogeneity}

In this section, we examine heterogeneity in the relationship between the average Bagrut score and long-term schooling and economic outcomes using the variation generated by pollution. We stratify our data by comparing three groups: boys and girls, academically stronger and weaker students, and students from high and low socioeconomic background. We begin with an analysis of the first stage relationship between pollution and test scores in the three sub-samples. Our motivation for this stratification is twofold. First, we have a prior that asthma rates are higher among boys and among those of lower SES. Insofar as we observe larger effects for these groups, it sheds light on a possible mechanism for our finding, and implies that our result is being driven partly by a physiological mechanism. Second, in terms of fairness, it is worth considering how these exams affect different students. Since these exams are often the gatekeeper for prized occupations in Israel, it is worth investigating how different students are able to capitalize on these forms of achievement.

\section{A. Heterogeneity in the Responsiveness to Pollution}

We first examine whether there is heterogeneity in the relationship between scores and pollution

\footnotetext{
${ }^{16}$ Willis and Rosen (1979) find that, in a sample of World War II veterans, comparative advantage dictates whether people sort into higher education. This is consistent with our findings, which indicate that there is almost no marginal value of academic achievement for the lower ability students.
} 
by building on a set of stylized facts regarding which groups would be most sensitive to poor air quality, taken from an extensive medical literature. First, Israeli boys are more likely to be asthmatic than Israeli girls (Laor et al. 1993). Second, children of lower economic status are known to have higher rates of asthma and respiratory illnesses (Eriksson et al. 2006, Basagana et al. 2004). Third, Laor et al. (1993) also found that Ashdkenazic Jews (ethnic origin from America and Europe) have 63\% higher incidence of these illnesses than Sephardim (ethnic origin from Africa and Asia). This gives a rich set of potential comparisons for gauging whether asthma (or other respiratory illnesses) is a mechanism for the observed reduced form relationship between pollution and exam outcomes.

We estimate models in the same manner as those reported in Table 2, based on panel data at the exam level, separately by sex, student quality, and student background (SES). These results are presented in Table A4. The evidence in Panel A suggest that boys are between 2 and 4 times more sensitive to pollution than girls. We posit that the difference could be partly generated by the different asthma rates in these cohorts. Another possibility is that male students are more likely to be affected by small cognitive decline and distraction, consistent with higher rates of Attention Deficit Disorder in males (Biederman et al. 2002). As shown in Panel B, a similar pattern is found when comparing between academically weaker and stronger students. When we stratify the students by whether their Magen score is above or below the median, our estimated treatment effects for $\mathrm{PM}_{2.5}$ are more than two times larger among those classified as low achievers. The results also indicate a similarity between results estimated with school and student fixed effects, which is reassuring since our results on earnings are estimated at the student level and rely on school fixed effects. Lastly, in Panel C, we stratify the sample by SES. It may be that poorer families are more affected by air pollution as well, due to lower ability to engage in compensating behavior (Neidell 2004). Poorer children also have higher incidence of asthma (Basagana et al. 2004, Eriksson et al. 2006). We proxy SES with the student's father's education, with high SES being students with a father above the median 
value in our sample. We again find evidence in support of an interpretation that the relationship between pollution and exam performance is driven by a physiological mechanism. ${ }^{17}$

\section{B. Heterogeneity in the Long-Term Consequences of the Bagrut}

In this section, we examine the long term schooling and economic consequences of the Bagrut for different sub-populations in Israel. We repeat the group breakdowns used earlier, dstratifying students by sex, quality, and socio-economic background. In Table 4, columns 1 and 2 of Panel A, we present estimates of the return to an additional point on the Bagrut using 2SLS, where the Bagrut composite score is treated as the endogenous regressor and $\mathrm{PM}_{2.5}$ is the instrument. Our results by student sex are reported in columns 1 and 2, and indicate that the return to an additional point is roughly $60 \%$ higher for boys than girls: 78 shekels vs 59 shekels ( $\$ 21$ vs $\$ 16)$. One explanation is that women choose less financially rewarding fields of study than men, even when they have similar qualifications, as a result of gender attitudes in Israel. It is also worth noting that although female labor force participation rates are relatively similar to the US, Israeli women have much higher fertility than their American counterparts. ${ }^{18}$ This may lead Israeli women to choose less lucrative professions than men and often work part time, which would be reflected in a lower payoff per additional year of higher education. In our context, this is plausible, since many Israelis work in government jobs which are lower-wage, offer more flexible work schedules, and have generous maternity leave policies. A second explanation is that this is driven by discrimination against women in the labor market, resulting in a lower payoff to an additional year of schooling.

\footnotetext{
${ }^{17}$ In Lavy, Ebenstein and Roth (2013), we examine the relationship between air pollution exposure and the probability of failing a Bagrut exam for each of these sub-populations. The results indicate that boys are more sensitive to $\mathrm{PM}_{2.5}$ than girls, lower quality students are more sensitive than stronger students, and students from lower SES backgrounds are more sensitive than those from higher SES backgrounds. For example, raising the fraction of days with very polluted air by 10 percentage points is associated with a .57 percentage point increase for boys in the chance of failing a particular Bagrut in models with student fixed effects. Girls appear largely unaffected, with the increased chance of not passing being statistically indistinguishable from zero. The gap is even more striking for student with low Magen scores: a 10 percentage point increase in the fraction of days with very polluted air is associated with a .59 percentage point increase in failure probability.

${ }^{18}$ Average fertility rates in Israel are 3.0, roughly $50 \%$ higher than the US rate of 2.0 (World Bank, 2010). However, employment rates are relatively similar. Among women 25-45, the employment rates among Israeli men and women were $80 \%$ and $61 \%$ respectively (Israel 1995 census), compared to rates in the US of $86 \%$ and $69 \%$ (US 2010 census).
} 
In columns 3 and 4, we find larger returns to a point among higher achievement students. Specifically, stronger students experience a 124 shekel return to each point, compared to only a 80 shekel return among lower quality students (\$34 vs \$22). We offer two explanations for this finding. First, it may be related to the instrument we are using; insofar as our estimate is a local average treatment effect where the disturbance to a student's true potential is relatively small, the estimated return to an additional point on the Bagrut will be larger among those who could participate in lucrative occupations. For weaker students, pollution is not affecting their already-low chance of being accepted into a very lucrative profession. A second explanation is that there are heterogeneous returns to different types of higher education. So, for example, the return to an additional year of studying economics might be different than the return to philosophy. Since Israeli majors have different standards for admission, with humanities having lower standards generally, our estimates may be picking up the differences between the return to different majors, which provide an avenue to different occupations. Unfortunately, our data do not contain information on area of study, precluding further examination into this hypothesis.

In columns 5 and 6, we observe very large differences between students of high and low SES. The return to an additional point is 105 shekels (\$28) among high SES, and roughly half that amount for low SES (56 shekels or \$15). Interestingly, this gap is even larger than when we had previously split the sample by Magen score in columns 1 and 2. This suggests that coming from a wealthier background raises the return to education significantly, and in a more dramatic way than even stratifying by student quality. One possible explanation is that parental income enables students to undertake longer and more costly academic paths, but results in them landing ultimately in more lucrative positions. Having a non-binding funding constraint could be a partial explanation for the higher return to higher education. Another explanation is that credentials and connections are complements, so students with greater social capital and qualifications can capitalize on their qualifications more than students from less privileged background.

In Panel B of Table 4, we examine the mechanisms for the aforementioned results by estimating 2SLS models where we instrument for a point with pollution and treat the Bagrut composite score as our endogenous regressor. We repeat our earlier analysis performed on the overall sample, and examine 3 
channels through which Bagrut scores may influence long run economic outcomes: by affecting the probability of receiving a matriculation certificate, by affecting enrollment rates in post-secondary institutions, and through its effect on total completed post-secondary education. Interestingly, we find that girls, weaker students, and lower SES background students are more affected by each additional instrumented point on the Bagrut than boys, stronger students, or higher SES background students. We interpret this as evidence that the stakes of each point is higher for students with lower labor-force attachment or less economic advantage - not necessarily economically in terms of the consequences for wages, but in terms of their likelihood of pursuing post-secondary education.

For example, if male students are committed to participating in a lucrative profession, they will perhaps be less dissuaded by a poor score; in Israel, students can attend a lower-ranked school in their field of study of choice, if they are denied admission in the top programs in Tel Aviv or Jerusalem. Likewise, stronger students and students from high SES background may proceed with their intended course of study in spite of a bad score. Greater commitment to the labor force or greater access financial resources may result in matriculation at campuses in other cities, such as Be'er Sheva, where students generally cannot live at home and need to pay for dormitories but often have lower Bagrut score thresholds for admission. Having sufficient economic resources could also facilitate a student retaking the exam in a subsequent year, lowering the stakes of a single bad outcome for students from privileged backgrounds. ${ }^{19}$ Our analysis of mechanisms highlights the disruptive effect of a poor Bagrut outcome on female and weaker/low SES students, and is further evidence that reliance on the Bagrut has questionable properties in terms of supporting a meritocratic environment.

\section{Heterogeneity in the Returns to Higher Education}

\footnotetext{
${ }^{19}$ Vigdor and Clotfelter found this to be important in the US context, where students from wealthier backgrounds are more likely to retake the SAT (2003). However, since Israeli high-school graduates immediately begin a period of military service ( 3 years for boys and 2 years for girls), retaking the exam is only possible with a long delay. Therefore, retaking the exam is relatively uncommon but could explain in part the weaker relationship between instrumented Bagrut scores and post-secondary education for students from high SES.
} 
In Table 5, we examine heterogeneity in the estimated return to education by sub-population in Israel using 2SLS, with pollution again as our instrument for Bagrut composite scores. Note that since pollution affects scores as well, this will not satisfy the exclusion restriction, but is worth exploring nonetheless to assess the economic magnitude of our estimated effects. In Panel A, where we stratify the sample by sex, we estimate that an additional 100 units of $\mathrm{PM}_{2.5}$ reduces male and female post-secondary schooling by 1.73 and 1.44 years respectively. We estimate that the return to an additional year of schooling is 888 shekels and 564 shekels respectively (\$240 versus \$152), suggesting that male students are more able to capitalize on post-secondary education, possibly due to the choice of more lucrative majors and professions, discrimination in the labor force, or due to their stronger labor-force attachment. We also find that stronger students are able to capitalize more from higher education: the wage return to post-secondary schooling is nearly twice as high among stronger students, with each year increasing wages by 1,131 shekels per month for strong students and only by 698 for weaker students. This pattern is even more extreme when we consider students stratified by SES: an additional year is worth 1,264 shekels to a student of high SES background, more than twice the return to low SES students (580 shekels). Similar to our discussion of the return to a point on the Bagrut, this highlights the interplay between achievement and status: the results indicate that the return to post-secondary education is largest among those most able to leverage this achievement, highlighting an additional avenue by which high stakes examinations can affect the wage distribution and wage inequality.

\section{Conclusion}

This paper has examined the relationship between transitory shocks to performance in high stakes exams and their long term consequences for determining college schooling attainment and earnings. We exploited variation in ambient air pollution during high-stakes examinations as an instrumental variable, and demonstrated that pollution affects student test scores on very important high-school exit exams, which in turn affects post-secondary schooling and long run earnings. Our analysis consisted of two parts. First, using a large sample of Israeli high-school Bagrut examinations (2000-2002), we presented evidence that 
there is a robust negative relationship between academic outcomes and random fluctuations in ambient pollution concentrations. Among Israeli sub-populations with higher rates of asthma and respiratory illnesses, our estimated treatment effects for $\mathrm{PM}_{2.5}$ are larger, suggesting that physiological impairment is a potential mechanism for our findings. Second, using matched data between students and their adult earnings, we find that ambient pollution exposure during the Bagrut has long-term consequences; students exposed to high levels of pollution during the Bagrut are less likely to receive a matriculation certificate, have fewer years of post-secondary schooling, and have lower wages when they are observed 8-10 years after high school graduation.

We argue that this is evidence that placing so much weight on Bagrut scores may reduce welfare for unlucky students and lead to allocative inefficiencies. As a result this will negatively affect the overall economy, as the mis-ranking of students due to variability in pollution exposure could result in poor assignment of workers to different occupations and reduce labor productivity. Our findings also suggest that the exams may be generating random variation in people's opportunities, consistent with recent concerns voiced by officials in the US regarding the reliance of the SATs for college admissions (Lewin 2014).

\section{References}

Angrist, J.D., and S.H. Chen. 2011. "Schooling and the Vietnam-Era GI Bill: Evidence from the Draft Lottery." American Economic Journal: Applied Economics, 3(2): 96-118.

Angrist, J. and Lavy, V. 1999. “Using Maimonides' Rule to Estimate the Effect of Class Size on Scholastic Achievement." Quarterly Journal of Economics, 114(2), 533-575.

Angus, R. and R. Heslegrave, and W. Stewart Myles. 1985. "Effects of Prolonged Sleep Deprivation, With and Without Chronic Physical Exercise, on Mood and Performance.” Psychophysiology, 22(3):276-282.

Basagaña, X., S. Jordi, K. Manolis, Zock, J., Duran-Tauleria, Enric, J.D., Burney, P. and Josep Maria Anto. 2004. "Socioeconomic status and asthma prevalence in young adults: the European Community Respiratory Health Survey.” American Journal of Epidemiology, 160: 178-188.

Bell, M., JK and Lin Z. 2008. "The effect of sandstorms and air pollution on cause-specific hospital admissions in Taipei, Taiwan." Occupational and Environmental Medicine, 65: 104-111. 
Bertrand, M., and S. Mullainathan. 2001. "Are CEO's Rewarded for Luck? The Ones Without Principals Are." Quarterly Journal of Economics, 116(3):901-932.

Biederman, J.M., E. Faraone, S. Braaten, E. Doyle, A. Spencer, T. Wilens, T. Frazier, E. and M.A. Johnson. 2002. "Influence of Gender on Attention Deficit Hyperactivity Disorder in Children Referred to a Psychiatric Clinic." The American Journal of Psychiatry, 159: 36-42.

Braniš, M., ̌̌. Pavla, and M. Domasová. 2005. "The effect of outdoor air and indoor human activity on mass concentrations of PM10, PM2.5, and PM1 in a classroom." Environmental Research, 99: 143149.

Calderón-Garcidueñas, L., Mora-Tiscareño, A., Ontiveros, E., Gómez-Garza, G., Barragán-Mejía, G., Broadway, J., Chapman, S., Valencia-Salazar, G., Jewells, V., Maronpot, RR., Henríquez-Roldán, C., Pérez-Guillé, B., Torres-Jardón, R., Herrit, L., Brooks, D., Osnaya-Brizuela, N., Monroy, M., GonzálezMaciel, A., Reynoso-Robles, R., Villarreal-Calderon, R., Solt. A., and R. Engle. 2008. "Air pollution, cognitive deficits and brain abnormalities: a pilot study with children and dogs." Brain and Cognition, 68(2): 117-127.

Cawley, J, J. Heckman and E. Vytlacil. 2001. "Three observations on wages and cognitive ability.” Labour Economics 8:419-442.

Chang, Tom, Joshua Graff Zivin, Tal Gross, Matthew Neidell. 2014. "Particulate Pollution and the Productivity of Pear Packers". NBER WP 19444.

Chay, Kenneth Y and Michael Greenstone. 2003. "The Impact of Air Pollution on Infant Mortality: Evidence from Geographic Variation in Pollution Shocks Induced by a Recession.” Quarterly Journal of Economics 118(3):1121-116

Clark, D. and L. Sokoloff. 1999. "Circulation and energy metabolism of the brain," in G. Siegel, B. Agranoff, R. Albers, S. Fisher and M. Uhler, eds., Basic Neurochemistry. Molecular, Cellular and Medical Aspects, Lippincott-Raven, pp. 637-670.

Dockery, W., and C. Pope. 1996. "Epidemiology of Acute Health Effects: Summary of Time Series Studies." in R. Wilson and J. Spengler, eds., Particles in Our Air, Harvard University Press, 123-148.

Eriksson K., Hedlund U., and E. Ronmark. 2006. "Socio-economic status is related to incidence of asthma and respiratory symptoms in adults." European Respiratory Journal, 28(2): 303-310.

Frisch, R. 2009. “The Economic Returns to Schooling in Israel”. Israel Economic Review (7)1:113-141.

Graff Z., J. S. and M. J. Neidell. 2012. "The Impact of Pollution on Worker Productivity." American Economic Review 102:3652-3673.

Jarvis, Martin. 1993. Does caffeine intake enhance absolute levels of cognitive performance? Psychopharmacology 110:45-52. 
Lewin, Tamar. “A New SAT Aims to Realign With Schoolwork”. The New York Times 5 March 2014; accessed at: http://www.nytimes.com/2014/03/06/education/major-changes-in-sat-announced-bycollege-board.html?.r=0. 10 March 2014.

Kampa, M., and E. Castanas. 2007. "Human health effects of air pollution." Environmental Pollution, 151: 362-367.

Laor, A., Cohen, L., and Y Danon. 1993. "Effects of time, sex, ethnic origin, and area of residence on prevalence of asthma in Israeli adolescents." British Medical Journal, 307(6908): 841-844.

Lavy, V. 2009. "Performance Pay and Teachers' Effort, Productivity and Grading Ethics", American Economic Review, 99(5): 1979-2011.

Lavy, V., A. Ebenstein and S. Roth, "The Impact of Short Term Exposure to Ambient Air Pollution on Cognitive Performance", Mimeo 2013.

Moretti, E. and M. Neidell. 2011. "Pollution, Health, and Avoidance Behavior Evidence from the Ports of Los Angeles." The Journal of Human Resources, 46(1): 154-175.

Neidell, M. 2004. "Air pollution, health, and socio-economic status: the effect of outdoor air quality on childhood asthma." Journal of Health Economics, 23: 1209-1236.

Oreopoulos, P., von Wachter, T. and Heisz, A. 2012 "The Short-and Long-Term Career Effects of Graduating in a Recession.” American Economic Journal: Applied Economics, 4(1): 1-29.

Oreopoulos, P. and U. Petronijevic, 2013. "Making College Worth It: A Review of Research on the Returns to Higher Education," NBER Working Papers 19053.

Pope, C. III, Bates, D., and M. Raizenne. 1995. "Health Effects of Particulate Air Pollution: Time for Reassessment?" Environmental Health Perspectives, 103: 472-480.

Pope, C. III, and D. Dockery. 2006. "Critical Review-Health effects of fine particulate air pollution: Lines that connect." Journal of the Air and Waste Management Association, 56: 709-742.

Vigdor, Jacob L. and C. Clotfelter. 2003. "Retaking the SAT”. Journal of Human Resources 38:1-33.

Schlenker, W. and W. R. Walker. 2011. "Airports, Air Pollution, and Contemporaneous Health." NBER Working Paper \#17684.

Winerip, M. 2005. "SAT Essay Test Rewards Length and Ignores Errors". New York Times, May 5th.

Willis, R. and S. Rosen. 1979. "Education and Self-selection.” Journal of Political Economy, 87(5):S7S36. 


\section{Table 1}

Summary Statistics: Particulate Matter Exposure and Israeli Bagrut Scores

\begin{tabular}{|c|c|c|c|c|c|}
\hline \multirow[b]{2}{*}{ Variable } & \multirow[b]{2}{*}{$\begin{array}{l}\text { All } \\
(1)\end{array}$} & \multicolumn{2}{|c|}{ By Sex } & \multicolumn{2}{|c|}{ 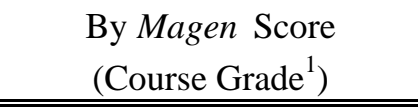 } \\
\hline & & $\begin{array}{l}\text { Boys } \\
(2)\end{array}$ & $\begin{array}{l}\text { Girls } \\
(3)\end{array}$ & $\begin{array}{c}\text { Low Scores } \\
(4)\end{array}$ & $\begin{array}{c}\text { High Scores } \\
(5)\end{array}$ \\
\hline \multicolumn{6}{|c|}{ Panel A: Exam-Level Data } \\
\hline \multicolumn{6}{|l|}{ Pollution Measures } \\
\hline $\begin{array}{l}\mathrm{PM}_{2.5} \\
\left(\mu \mathrm{g} / \mathrm{m}^{3}\right)\end{array}$ & $\begin{array}{c}21.05 \\
(10.86)\end{array}$ & $\begin{array}{c}20.89 \\
(10.57)\end{array}$ & $\begin{array}{c}21.18 \\
(11.10)\end{array}$ & $\begin{array}{c}21.15 \\
(10.88)\end{array}$ & $\begin{array}{c}20.96 \\
(10.87)\end{array}$ \\
\hline $\begin{array}{l}\mathrm{PM}_{2.5} \\
\text { (AQI Index) }\end{array}$ & $\begin{array}{c}59.74 \\
(22.81)\end{array}$ & $\begin{array}{c}59.47 \\
(22.50)\end{array}$ & $\begin{array}{c}59.98 \\
(23.08)\end{array}$ & $\begin{array}{c}60.01 \\
(22.89)\end{array}$ & $\begin{array}{c}59.51 \\
(22.75)\end{array}$ \\
\hline $\begin{array}{l}\mathrm{PM}_{2.5} \\
(\mathrm{AQI} \geq 101)\end{array}$ & $\begin{array}{c}0.05 \\
(0.21)\end{array}$ & $\begin{array}{c}0.05 \\
(0.21)\end{array}$ & $\begin{array}{c}0.05 \\
(0.22)\end{array}$ & $\begin{array}{c}0.05 \\
(0.22)\end{array}$ & $\begin{array}{c}0.05 \\
(0.21)\end{array}$ \\
\hline \multicolumn{6}{|l|}{ Examination Outcomes } \\
\hline $\begin{array}{l}\text { Bagrut Exam Score } \\
\text { (1-100 points) }\end{array}$ & $\begin{array}{c}70.76 \\
(23.74)\end{array}$ & $\begin{array}{c}68.91 \\
(24.86)\end{array}$ & $\begin{array}{c}72.33 \\
(22.64)\end{array}$ & $\begin{array}{c}53.22 \\
(30.69)\end{array}$ & $\begin{array}{c}77.10 \\
(22.18)\end{array}$ \\
\hline $\begin{array}{l}\text { Failed a Bagrut Exam } \\
\text { (1=yes) }\end{array}$ & $\begin{array}{c}0.19 \\
(0.39)\end{array}$ & $\begin{array}{c}0.21 \\
(0.41)\end{array}$ & $\begin{array}{c}0.17 \\
(0.37)\end{array}$ & $\begin{array}{c}0.33 \\
(0.47)\end{array}$ & $\begin{array}{c}0.04 \\
(0.19)\end{array}$ \\
\hline $\begin{array}{l}\text { Magen Score } \\
\text { (1-100 points) }\end{array}$ & $\begin{array}{c}75.45 \\
(21.37)\end{array}$ & $\begin{array}{c}73.27 \\
(22.50)\end{array}$ & $\begin{array}{l}77.30 \\
(20.19)\end{array}$ & $\begin{array}{c}64.09 \\
(23.25)\end{array}$ & $\begin{array}{c}86.93 \\
(10.47)\end{array}$ \\
\hline \multicolumn{6}{|l|}{ Climate Controls } \\
\hline $\begin{array}{l}\text { Temperature } \\
\text { (celsius) }\end{array}$ & $\begin{array}{l}23.81 \\
(2.61)\end{array}$ & $\begin{array}{l}23.81 \\
(2.61)\end{array}$ & $\begin{array}{l}23.82 \\
(2.62)\end{array}$ & $\begin{array}{l}23.84 \\
(2.66)\end{array}$ & $\begin{array}{l}23.83 \\
(2.50)\end{array}$ \\
\hline $\begin{array}{l}\text { Relative Humidity } \\
\text { (percent saturation) }\end{array}$ & $\begin{array}{c}50.90 \\
(14.71)\end{array}$ & $\begin{array}{c}50.86 \\
(14.52)\end{array}$ & $\begin{array}{c}50.94 \\
(14.87)\end{array}$ & $\begin{array}{c}50.98 \\
(15.08)\end{array}$ & $\begin{array}{c}50.95 \\
(14.35)\end{array}$ \\
\hline Observations & 415,219 & 190,410 & 224,809 & 206,571 & 204,527 \\
\hline \multicolumn{6}{|c|}{ Panel B: Student-Level Data } \\
\hline \multicolumn{6}{|c|}{ Demographic Information } \\
\hline $\begin{array}{l}\text { Mother's Education } \\
\text { (years) }\end{array}$ & $\begin{array}{l}11.44 \\
(5.04)\end{array}$ & $\begin{array}{l}11.60 \\
(5.09)\end{array}$ & $\begin{array}{l}11.30 \\
(5.00)\end{array}$ & $\begin{array}{l}10.79 \\
(4.87)\end{array}$ & $\begin{array}{l}12.08 \\
(5.13)\end{array}$ \\
\hline $\begin{array}{l}\text { Father's Education } \\
\text { (years) }\end{array}$ & $\begin{array}{l}11.62 \\
(5.03)\end{array}$ & $\begin{array}{l}11.83 \\
(5.02)\end{array}$ & $\begin{array}{l}11.44 \\
(5.03)\end{array}$ & $\begin{array}{l}10.85 \\
(4.84)\end{array}$ & $\begin{array}{l}12.39 \\
(5.10)\end{array}$ \\
\hline Number of Siblings & $\begin{array}{c}2.02 \\
(1.58)\end{array}$ & $\begin{array}{c}1.95 \\
(1.49)\end{array}$ & $\begin{array}{c}2.07 \\
(1.65)\end{array}$ & $\begin{array}{c}2.03 \\
(1.61)\end{array}$ & $\begin{array}{c}2.00 \\
(1.55)\end{array}$ \\
\hline \multicolumn{6}{|c|}{ Bagrut Outcomes and Matriculation Certification Rates } \\
\hline Bagrut Composite Score & $\begin{array}{l}70.76 \\
(23.74)\end{array}$ & $\begin{array}{l}68.91 \\
(24.86)\end{array}$ & $\begin{array}{l}72.33 \\
(22.64)\end{array}$ & $\begin{array}{l}53.22 \\
(30.69)\end{array}$ & $\begin{array}{l}77.10 \\
(22.18)\end{array}$ \\
\hline
\end{tabular}




$\begin{array}{llllll}\text { Matriculation } & 0.68 & 0.64 & 0.71 & 0.48 & 0.91 \\ \text { Certification Rate } & (0.47) & (0.48) & (0.45) & (0.50) & (0.28) \\ \begin{array}{l}\text { Post-Secondary Enrollment Rates } \\ \text { Any Post-Secondary }\end{array} & 0.631 & 0.602 & 0.656 & 0.475 & 0.821 \\ \text { University } & 0.274 & 0.258 & 0.289 & 0.115 & 0.469 \\ \text { Academic Colleges } & 0.248 & 0.253 & 0.244 & 0.244 & 0.253 \\ \text { Teacher \& Semi-eng. } & 0.070 & 0.063 & 0.076 & 0.078 & 0.059 \\ \text { Other }^{2} & 0.046 & 0.036 & 0.055 & 0.046 & 0.047\end{array}$

Post-Secondary Schooling in Years

\begin{tabular}{lccccc} 
Any Post-Secondary & 2.25 & 2.05 & 2.42 & 1.45 & 3.23 \\
& $(2.15)$ & $(2.10)$ & $(2.18)$ & $(1.86)$ & $(2.08)$ \\
University & 1.03 & 0.95 & 1.10 & 0.35 & 1.85 \\
& $(1.90)$ & $(1.83)$ & $(1.95)$ & $(1.13)$ & $(2.28)$ \\
Academic Colleges & 0.83 & 0.80 & 0.85 & 0.73 & 0.95 \\
& $(1.47)$ & $(1.44)$ & $(1.50)$ & $(1.38)$ & $(1.57)$ \\
$\begin{array}{l}\text { Teachers \& Semi- } \\
\text { engineering }\end{array}$ & 0.26 & 0.21 & 0.31 & 0.25 & 0.27 \\
$\begin{array}{l}\text { Adult Earnings } \\
\text { Monthly Wages }\end{array}$ & $(0.87)$ & $(0.68)$ & $(1.00)$ & $(0.82)$ & $(0.92)$ \\
$\begin{array}{l}{ }^{3} \text { NIS 2010) } \\
\text { Observations }\end{array}$ & 5,084 & 5,531 & 4,699 & & \\
\hline
\end{tabular}

Notes : Standard deviations are in parentheses. In Panel A, each observation represents a Bagrut exam. The measure of pollution is particulate matter smaller than 2.5 microns, or $\mathrm{PM}_{2.5}$. The AQI value for each reading is calculated from a formula that converts micrograms $(\mu \mathrm{g} / \mathrm{m} 3)$ into a 1-500 index value. Relative humidity is the amount of moisture in the air as a share of what the air can hold at that temperature. ${ }^{1}$ The low and high subsamples were based on being above or below the median of a student's average Magen score over all subjects. In Panel B, each observation represents a student. The pollution and climate controls are averages over a student's exams. Receiving a matriculation certificate is determined by a combination of the student's average Bagrut and Magen score. ${ }^{2}$ The other programs include technical schools, non-academic colleges, and smaller schools. ${ }^{3}$ Wages are repoted in monthly New Israeli Shekels ( $\$ 1=3.6$ NIS) and are taken for 2010 from the students who took Bagrut examinations between 2000 and 2002. The schooling and wage outcomes were made available by the Israeli National Insurance Institute (Bituach Leumi). Each student's record contains whether they matriculated at a post-secondary institution, and the number of years they were enrolled at the institution. 
Table 2

Reduced Form Effect of Particulate Matter On Post-Secondary Education and Adult Earnings

\begin{tabular}{|c|c|c|c|}
\hline & \multirow{2}{*}{$\begin{array}{c}\text { Pooled OLS } \\
\text { Controls } \\
(1)\end{array}$} & \multicolumn{2}{|c|}{ Fixed Effects } \\
\hline & & $\begin{array}{l}\text { City } \\
(2) \\
\end{array}$ & $\begin{array}{c}\text { School } \\
(3)\end{array}$ \\
\hline Bagrut Composite Score & $\begin{array}{c}-6.7 \\
(0.84)\end{array}$ & $\begin{array}{l}-26.6 \\
(1.28)\end{array}$ & $\begin{array}{l}-16.4 \\
(1.85)\end{array}$ \\
\hline Number of Bagrut Failures & $\begin{array}{c}0.81 \\
(0.84)\end{array}$ & $\begin{array}{c}1.97 \\
(0.11)\end{array}$ & $\begin{array}{c}1.06 \\
(0.20)\end{array}$ \\
\hline Proportion of Bagrut Failures & $\begin{array}{c}0.08 \\
(0.01)\end{array}$ & $\begin{array}{c}0.27 \\
(0.02)\end{array}$ & $\begin{array}{c}0.15 \\
(0.03)\end{array}$ \\
\hline Matriculation Certification & $\begin{array}{l}-0.23 \\
(0.02)\end{array}$ & $\begin{array}{l}-0.53 \\
(0.03)\end{array}$ & $\begin{array}{l}-0.33 \\
(0.05)\end{array}$ \\
\hline $\begin{array}{l}\text { Enrolled in Post Secondary } \\
\text { Institution ( } 1=\text { yes) }\end{array}$ & $\begin{array}{l}-0.09 \\
(0.02)\end{array}$ & $\begin{array}{l}-0.50 \\
(0.03)\end{array}$ & $\begin{array}{l}-0.31 \\
(0.04)\end{array}$ \\
\hline $\begin{array}{l}\text { Completed Years of Post- } \\
\text { secondary Education }\end{array}$ & $\begin{array}{l}-0.67 \\
(0.09)\end{array}$ & $\begin{array}{l}-2.36 \\
(0.13)\end{array}$ & $\begin{array}{l}-1.52 \\
(0.18)\end{array}$ \\
\hline $\begin{array}{l}\text { Average Monthly Earnings } \\
\text { (NIS) }\end{array}$ & $\begin{array}{c}-1,548 \\
(326)\end{array}$ & $\begin{array}{c}-1,199 \\
(331)\end{array}$ & $\begin{array}{c}-1,093 \\
(344)\end{array}$ \\
\hline
\end{tabular}

Notes: Each cell in the table represents a separate regression. The table reports the relationship between average $\mathrm{PM}_{2.5}$ (AQI) during the Bagrut and the listed outcome, estimated using the student-level sample described in Table 1. All regressions include suppressed controls for average temperature and humidity during the Bagrut, mother's and father's years of schooling, sex, and age in 2010. The coefficients are reported per 100 units of AQI. Standard errors are clustered at the school level, are heteroskedastic-consistent, and are reported below the coefficients in parentheses. 
Table 3

The Economic and Academic Return to the Bagrut Composite Score

\begin{tabular}{|c|c|c|c|}
\hline & \multirow{2}{*}{$\begin{array}{c}\text { Pooled OLS } \\
\text { Controls } \\
(1)\end{array}$} & \multicolumn{2}{|c|}{ Fixed Effects } \\
\hline & & $\begin{array}{l}\text { City } \\
(2)\end{array}$ & $\begin{array}{l}\text { School } \\
(3)\end{array}$ \\
\hline \multicolumn{4}{|c|}{$\begin{array}{l}\text { Panel A: Effect of the Bagrut Composite Score on Adult Earnings using } \\
P_{2.5} \text { (AQI) as an IV }\end{array}$} \\
\hline First Stage & $\begin{array}{l}-6.66 \\
(0.84)\end{array}$ & $\begin{array}{l}-26.57 \\
(1.27)\end{array}$ & $\begin{array}{l}-16.38 \\
(1.85)\end{array}$ \\
\hline Reduced Form & $\begin{array}{l}-1528 \\
(324)\end{array}$ & $\begin{array}{l}-1203 \\
(327)\end{array}$ & $\begin{array}{l}-1073 \\
(341)\end{array}$ \\
\hline 2SLS & $\begin{array}{c}229 \\
(147)\end{array}$ & $\begin{array}{c}45 \\
(13)\end{array}$ & $\begin{array}{c}66 \\
(21)\end{array}$ \\
\hline \multicolumn{4}{|c|}{$\begin{array}{l}\text { Panel B: Effect of the Bagrut Composite Score on Follow Up Academic Outcomes } \\
\text { using PM }{ }_{2.5} \text { (AQI) as an IV }\end{array}$} \\
\hline Matriculation Certification & $\begin{array}{c}0.034 \\
(0.011)\end{array}$ & $\begin{array}{l}0.020 \\
(0.002)\end{array}$ & $\begin{array}{c}0.020 \\
(0.002)\end{array}$ \\
\hline $\begin{array}{l}\text { Enrolled in Post Secondary } \\
\text { Institution (1=yes) }\end{array}$ & $\begin{array}{c}0.016 \\
(0.006)\end{array}$ & $\begin{array}{c}0.019 \\
(0.002)\end{array}$ & $\begin{array}{c}0.019 \\
(0.002)\end{array}$ \\
\hline $\begin{array}{l}\text { Completed Years of Post- } \\
\text { secondary Education }\end{array}$ & $\begin{array}{c}0.105 \\
(0.026)\end{array}$ & $\begin{array}{c}0.089 \\
(0.006)\end{array}$ & $\begin{array}{c}0.092 \\
(0.009)\end{array}$ \\
\hline \multicolumn{4}{|c|}{ Panel C: Estimated Return to Post-Secondary Education using PM 2.5 (AQI) as an 1} \\
\hline First Stage & $\begin{array}{l}-0.67 \\
(0.09)\end{array}$ & $\begin{array}{l}-2.36 \\
(0.13)\end{array}$ & $\begin{array}{l}-1.52 \\
(0.18)\end{array}$ \\
\hline Reduced Form & $\begin{array}{l}-1548 \\
(326)\end{array}$ & $\begin{array}{l}-1199 \\
(331)\end{array}$ & $\begin{array}{l}-1093 \\
(344)\end{array}$ \\
\hline 2SLS & $\begin{array}{c}2278 \\
(1343)\end{array}$ & $\begin{array}{c}509 \\
(139)\end{array}$ & $\begin{array}{c}707 \\
(219)\end{array}$ \\
\hline
\end{tabular}

Notes : Each cell in the table represents a separate regression. The regressions are estimated in the same manner as those reported in Table 4. In Panel A, we present 2SLS models of the relationship between the Bagrut Composite Score and Adult Earnings using $\mathrm{PM}_{2.5}$ (AQI) as an instrumental variable. In Panel B, we present 2SLS models of the relationship between Bagrut Composite Score and other academic outcomes, using $\mathrm{PM}_{2.5}$ (AQI) as an instrumental variable. In Panel C, we estimate the implied return to post-secondary schooling using $\mathrm{PM}_{2.5}$ (AQI) as the instrument. Standard errors are clustered at the school level, are heteroskedastic-consistent, and are reported below the coefficients in parentheses. 


\section{Table 4}

Heterogeneity in the Economic and Academic Return to the Bagrut Composite Score

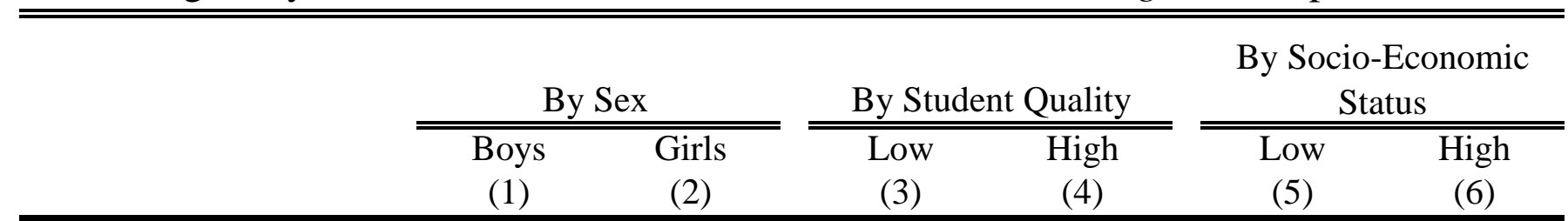

Panel A: Effect of the Bagrut Composite Score on Adults Earnings using PM ${ }_{2.5}(\mathrm{AQI})$ as an IV

\begin{tabular}{lcccccc} 
First Stage & -19.72 & -13.69 & -6.61 & -12.15 & -13.22 & -21.10 \\
\multirow{2}{*}{ Reduced Form } & $(2.65)$ & $(1.94)$ & $(1.84)$ & $(1.65)$ & $(1.98)$ & $(2.52)$ \\
& $-1,540$ & -810 & -530 & $-1,510$ & -747 & $-2,205$ \\
\multirow{2}{*}{ 2SLS } & $(495)$ & $(421)$ & $(352)$ & $(622)$ & $(288)$ & $(734)$ \\
& 78 & 59 & 80 & 124 & 56 & 105 \\
& $(27)$ & $(30)$ & $(58)$ & $(51)$ & $(24)$ & $(32)$
\end{tabular}

Panel B: Effect of the Bagrut Composite Score on Follow up Academic Outcomes

\begin{tabular}{|c|c|c|c|c|c|c|}
\hline $\begin{array}{l}\text { Matriculation } \\
\text { Certification }\end{array}$ & $\begin{array}{c}0.017 \\
(0.002)\end{array}$ & $\begin{array}{c}0.025 \\
(0.003)\end{array}$ & $\begin{array}{c}0.032 \\
(0.008)\end{array}$ & $\begin{array}{c}0.011 \\
(0.004)\end{array}$ & $\begin{array}{c}0.023 \\
(0.003)\end{array}$ & $\begin{array}{c}0.015 \\
(0.002)\end{array}$ \\
\hline $\begin{array}{l}\text { Enrolled in Post } \\
\text { Secondary } \\
\text { Institution (1=yes) }\end{array}$ & $\begin{array}{c}0.018 \\
(0.002)\end{array}$ & $\begin{array}{c}0.020 \\
(0.003)\end{array}$ & $\begin{array}{c}0.029 \\
(0.008)\end{array}$ & $\begin{array}{c}0.019 \\
(0.004)\end{array}$ & $\begin{array}{c}0.021 \\
(0.003)\end{array}$ & $\begin{array}{c}0.013 \\
(0.002)\end{array}$ \\
\hline $\begin{array}{l}\text { Completed Years } \\
\text { of Post-secondary } \\
\text { Education }\end{array}$ & $\begin{array}{c}0.087 \\
(0.010)\end{array}$ & $\begin{array}{c}0.108 \\
(0.014)\end{array}$ & $\begin{array}{c}0.108 \\
(0.030)\end{array}$ & $\begin{array}{c}0.118 \\
(0.015)\end{array}$ & $\begin{array}{c}0.096 \\
(0.013)\end{array}$ & $\begin{array}{c}0.085 \\
(0.010)\end{array}$ \\
\hline
\end{tabular}

Notes: Each cell in the table represents a separate regression. The regressions are estimated in the same manner as those reported in Table 4. Student quality is determined by whether the student's average Magen score was above or below the median. High SES is defined as children whose father was above the median level of education. 
Table 5

Heterogeneity in the Estimated Return to Post-Secondary Education

\begin{tabular}{|c|c|c|c|c|c|c|}
\hline & \multicolumn{2}{|c|}{ By Sex } & \multicolumn{2}{|c|}{ By Student Quality } & \multicolumn{2}{|c|}{$\begin{array}{c}\text { By Socio-Economic } \\
\text { Status } \\
\end{array}$} \\
\hline & $\begin{array}{c}\text { Boys } \\
(1)\end{array}$ & $\begin{array}{c}\text { Girls } \\
(2)\end{array}$ & $\begin{array}{l}\text { Low } \\
\text { (3) }\end{array}$ & $\begin{array}{l}\text { High } \\
(4)\end{array}$ & $\begin{array}{c}\text { Low } \\
(5)\end{array}$ & $\begin{array}{c}\text { High } \\
(6)\end{array}$ \\
\hline First Stage & $\begin{array}{l}-1.73 \\
(0.22)\end{array}$ & $\begin{array}{l}-1.44 \\
(0.23)\end{array}$ & $\begin{array}{l}-0.76 \\
(0.15)\end{array}$ & $\begin{array}{l}-1.33 \\
(0.27)\end{array}$ & $\begin{array}{l}-1.29 \\
(0.19)\end{array}$ & $\begin{array}{l}-1.74 \\
(0.29)\end{array}$ \\
\hline Reduced Form & $\begin{array}{c}-1,559 \\
(498)\end{array}$ & $\begin{array}{l}-839 \\
(428)\end{array}$ & $\begin{array}{l}-521 \\
(355)\end{array}$ & $\begin{array}{c}-1,568 \\
(617)\end{array}$ & $\begin{array}{l}-743 \\
(288)\end{array}$ & $\begin{array}{l}-2,251 \\
(747)\end{array}$ \\
\hline 2SLS & $\begin{array}{c}888 \\
(296)\end{array}$ & $\begin{array}{c}564 \\
(265)\end{array}$ & $\begin{array}{c}698 \\
(484)\end{array}$ & $\begin{array}{l}1,131 \\
(454)\end{array}$ & $\begin{array}{c}580 \\
(235)\end{array}$ & $\begin{array}{l}1,264 \\
(405)\end{array}$ \\
\hline
\end{tabular}

Notes: Each cell in the table represents a separate regression. Standard errors are clustered by school. Each estimate is in terms of a single year of additional post-secondary schooling, and the instrument is $\mathrm{PM}_{2.5}(\mathrm{AQI})$. Student quality is determined by whether the student's average Magen score was above or below the median. High SES is defined as children whose father was above the median level of education. Standard errors are heteroskedastic-consistent and are reported below the coefficients in parentheses. 


\section{Figure 1}

Locations of Major Cities and Air Quality Monitoring Stations in

Israel

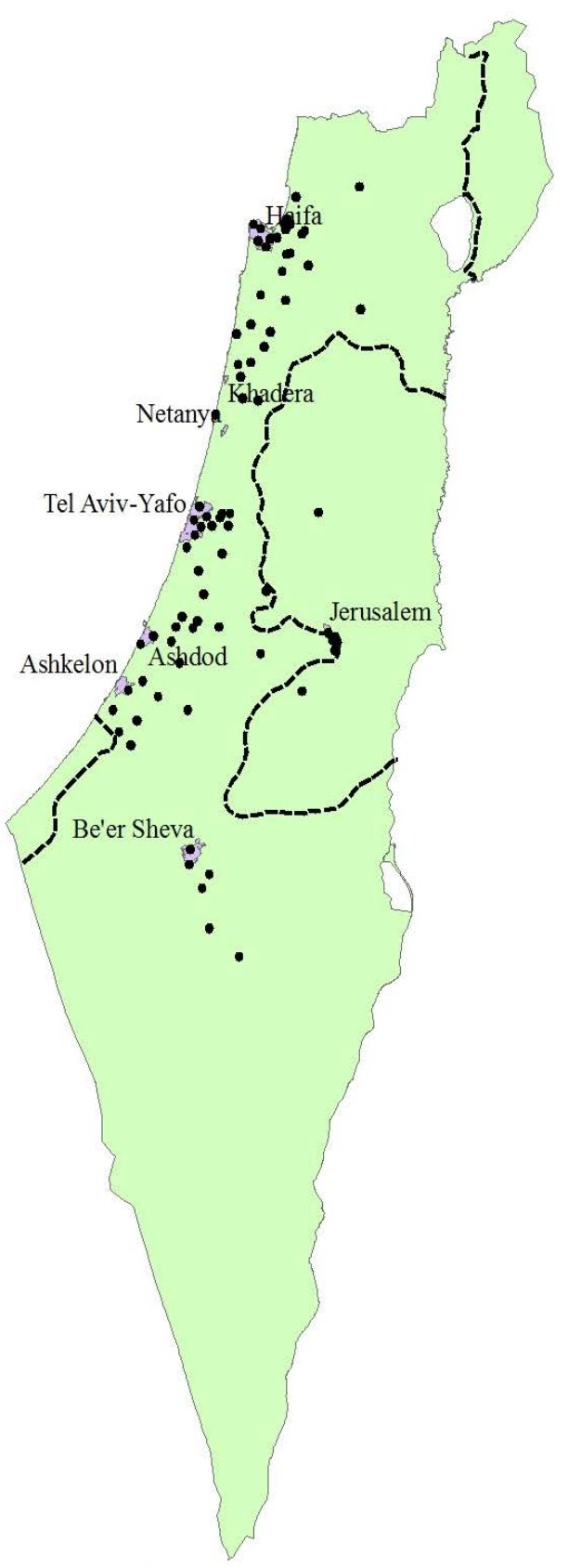

- Air Pollution Monitoring Stations

---- 1967 Border Line

$\square$ Major Cities

Notes: The boundaries of Israel are reported in the plot, with the main cities shaded in. 
Table A1

Balancing Tests: Assessing the Relationship between

Students' Characteristics and Pollution

\begin{tabular}{|c|c|c|}
\hline Variable & $\begin{array}{c}\text { Pooled OLS } \\
(1) \\
\end{array}$ & $\begin{array}{c}\text { School Fixed Effects } \\
(2)\end{array}$ \\
\hline $\begin{array}{l}\text { Female } \\
\text { (1=yes) }\end{array}$ & $\begin{array}{c}0.00 \\
(0.00)\end{array}$ & $\begin{array}{c}0.10 \\
(0.00)\end{array}$ \\
\hline Father's Education & $\begin{array}{c}0.10 \\
(1.00)\end{array}$ & $\begin{array}{c}0.40 \\
(0.50)\end{array}$ \\
\hline Mother's Education & $\begin{array}{c}0.30 \\
(1.00)\end{array}$ & $\begin{array}{l}-0.10 \\
(0.60)\end{array}$ \\
\hline Number of Siblings & $\begin{array}{c}0.60 \\
(0.30)\end{array}$ & $\begin{array}{c}0.30 \\
(0.10)\end{array}$ \\
\hline $\begin{array}{l}\text { Ashkenazi } \\
\text { (1=yes) }\end{array}$ & $\begin{array}{c}0.00 \\
(0.00)\end{array}$ & $\begin{array}{c}0.00 \\
(0.00)\end{array}$ \\
\hline $\begin{array}{l}\text { Sephardi } \\
\text { (1=yes) }\end{array}$ & $\begin{array}{c}0.00 \\
(0.00)\end{array}$ & $\begin{array}{c}0.00 \\
(0.00)\end{array}$ \\
\hline $\begin{array}{l}\text { Father Born in Israel } \\
\text { (1=yes) }\end{array}$ & $\begin{array}{c}0.00 \\
(0.00)\end{array}$ & $\begin{array}{c}0.00 \\
(0.00)\end{array}$ \\
\hline Observations & 54,294 & 54,294 \\
\hline
\end{tabular}

Notes : Each cell in the table represents a separate regression, where the dependent variable is $\mathrm{PM}_{2.5}(\mathrm{AQI})$ and the independent variable is the coviate listed in the row. The regressions are estimated in the same manners as those presented in Table 2. 
Table A2

Relationship Between Particulate Matter Exposure During Previous Exams and Average Bagrut Scores at Conclusion of 12th Grade

\begin{tabular}{|c|c|c|c|c|}
\hline & \multicolumn{2}{|c|}{ Pooled OLS } & \multicolumn{2}{|c|}{ Fixed Effects } \\
\hline & $\begin{array}{c}\text { No controls } \\
\text { (1) }\end{array}$ & $\begin{array}{c}\text { Controls } \\
\text { (2) }\end{array}$ & $\begin{array}{c}\text { City } \\
(3)\end{array}$ & $\begin{array}{c}\text { Schoo } \\
(4)\end{array}$ \\
\hline \multicolumn{5}{|c|}{ Panel A: All Students } \\
\hline & $\begin{array}{l}-0.80 \\
(2.90)\end{array}$ & $\begin{array}{c}0.90 \\
(2.80)\end{array}$ & $\begin{array}{l}-0.40 \\
(3.50)\end{array}$ & $\begin{array}{c}1.70 \\
(2.10)\end{array}$ \\
\hline \multicolumn{5}{|c|}{ Panel B: By Sex } \\
\hline Boys & $\begin{array}{l}-0.90 \\
(3.40)\end{array}$ & $\begin{array}{c}0.30 \\
(3.50)\end{array}$ & $\begin{array}{l}-2.40 \\
(4.50)\end{array}$ & $\begin{array}{l}-0.70 \\
(2.80)\end{array}$ \\
\hline Girls & $\begin{array}{l}-1.20 \\
(2.80)\end{array}$ & $\begin{array}{c}1.30 \\
(3.00)\end{array}$ & $\begin{array}{c}0.90 \\
(3.60)\end{array}$ & $\begin{array}{c}4.00 \\
(2.40)\end{array}$ \\
\hline
\end{tabular}

\section{Panel C: By Student Quality}

$\begin{array}{lcccc}\text { Low Achievement } & 2.60 & 3.30 & 0.20 & 2.60 \\ \text { Students } & (2.50) & (2.50) & (3.30) & (2.30) \\ & & & & \\ \begin{array}{l}\text { High Achievement } \\ \text { Students }\end{array} & 1.30 & 1.40 & 1.10 & 2.30 \\ & (1.10) & (1.10) & (1.60) & (1.30)\end{array}$

\section{Panel D: By Socio-Economic Status (SES)}

$\begin{array}{lcccc}\text { Low SES } & -2.10 & 0.80 & 1.00 & 1.30 \\ & (2.90) & (3.00) & (3.50) & (2.30) \\ \text { High SES } & & & & \\ & 1.10 & 0.10 & -1.30 & 2.20 \\ & (3.00) & (2.80) & (4.10) & (2.80)\end{array}$

Notes : Each cell in the table represents a separate regression. The regressions are estimated in the same manners as those presented in Table 2. Student quality is determined by whether the student's average Magen score was above or below the median. High SES is defined as children whose father was above the median level of education. Standard errors are heteroskedastic-consistent and are reported below the coefficients in parentheses. 
Table A3

Particulate Matter's Impact on Post-Secondary Schooling by Type

\begin{tabular}{|c|c|c|c|c|}
\hline & \multicolumn{2}{|c|}{$\begin{array}{c}\text { LHS: Enrolled in Post- } \\
\text { Secondary Institution (1=yes) }\end{array}$} & \multicolumn{2}{|c|}{$\begin{array}{l}\text { LHS: Completed Years of Post- } \\
\text { Secondary Education }\end{array}$} \\
\hline & $\begin{array}{r}\text { City } \\
(1) \\
\end{array}$ & $\begin{array}{c}\text { School } \\
(2)\end{array}$ & $\begin{array}{c}\text { City } \\
(3) \\
\end{array}$ & $\begin{array}{c}\text { School } \\
(4)\end{array}$ \\
\hline $\begin{array}{l}\text { All Post-Secondary } \\
\text { Institutions }\end{array}$ & $\begin{array}{l}-0.495 \\
(0.069)\end{array}$ & $\begin{array}{l}-0.298 \\
(0.040)\end{array}$ & $\begin{array}{l}-2.353 \\
(0.306)\end{array}$ & $\begin{array}{l}-1.527 \\
(0.182)\end{array}$ \\
\hline Universities & $\begin{array}{l}-0.537 \\
(0.070)\end{array}$ & $\begin{array}{l}-0.369 \\
(0.044)\end{array}$ & $\begin{array}{l}-2.225 \\
(0.292)\end{array}$ & $\begin{array}{l}-1.568 \\
(0.184)\end{array}$ \\
\hline Academic Colleges & $\begin{array}{l}-0.086 \\
(0.042)\end{array}$ & $\begin{array}{c}0.019 \\
(0.031)\end{array}$ & $\begin{array}{l}-0.411 \\
(0.130)\end{array}$ & $\begin{array}{l}-0.036 \\
(0.102)\end{array}$ \\
\hline $\begin{array}{l}\text { Teacher and Semi- } \\
\text { engineering }\end{array}$ & $\begin{array}{c}0.039 \\
(0.030)\end{array}$ & $\begin{array}{c}0.008 \\
(0.019)\end{array}$ & $\begin{array}{c}0.119 \\
(0.070)\end{array}$ & $\begin{array}{c}0.058 \\
(0.049)\end{array}$ \\
\hline
\end{tabular}

Notes : Each cell in the table represents a separate regression. In each regression, the dependent variable is either enrollment (columns 1 and 2) or years of schooling (columns 3 and 4) at the listed academic type. The depdent variable is the average $\mathrm{PM}_{2.5}$ (AQI) exposure during the student's Bagrut examinations. The regressions are estimated with the same controls as those presented in Table 4, and the coefficients are reported per 100 units of $\mathrm{PM}_{2.5}$ (AQI). The column title reports whether fixed effects are included at the city or school level. Standard errors are heteroskedastic-consistent and are reported below the coefficients in parentheses. 


\section{Table A4}

Heterogeneity in the Impact of $\mathrm{PM}_{2.5}$ on Bagrut Test Scores

\begin{tabular}{|c|c|c|c|c|}
\hline & \multicolumn{2}{|c|}{$\mathrm{PM}_{2.5}(\mathrm{AQI}$ Index) } & \multicolumn{2}{|c|}{$\mathrm{PM}_{2.5}(\mathrm{AQI}>=101)$} \\
\hline & $\begin{array}{c}\text { School } \\
\text { (1) }\end{array}$ & $\begin{array}{c}\text { Student } \\
\text { (2) }\end{array}$ & $\begin{array}{c}\text { School } \\
\text { (3) }\end{array}$ & $\begin{array}{c}\text { Student } \\
\text { (4) }\end{array}$ \\
\hline \multicolumn{5}{|l|}{ Panel A: By Sex } \\
\hline Boys & $\begin{array}{l}-0.10 \\
(0.01)\end{array}$ & $\begin{array}{l}-0.08 \\
(0.01)\end{array}$ & $\begin{array}{l}-5.33 \\
(0.82)\end{array}$ & $\begin{array}{l}-4.10 \\
(0.87)\end{array}$ \\
\hline Girls & $\begin{array}{l}-0.04 \\
(0.01)\end{array}$ & $\begin{array}{l}-0.02 \\
(0.01)\end{array}$ & $\begin{array}{l}-0.66 \\
(0.80)\end{array}$ & $\begin{array}{l}-0.38 \\
(0.83)\end{array}$ \\
\hline \multicolumn{5}{|c|}{ Panel B: By Student Quality } \\
\hline $\begin{array}{l}\text { Low Achievement } \\
\text { Students }\end{array}$ & $\begin{array}{l}-0.08 \\
(0.01)\end{array}$ & $\begin{array}{l}-0.06 \\
(0.01)\end{array}$ & $\begin{array}{l}-3.86 \\
(1.04)\end{array}$ & $\begin{array}{l}-3.49 \\
(1.10)\end{array}$ \\
\hline $\begin{array}{l}\text { High Achievement } \\
\text { Students }\end{array}$ & $\begin{array}{l}-0.03 \\
(0.01)\end{array}$ & $\begin{array}{l}-0.03 \\
(0.01)\end{array}$ & $\begin{array}{l}-0.93 \\
(0.57)\end{array}$ & $\begin{array}{l}-0.76 \\
(0.68)\end{array}$ \\
\hline \multicolumn{5}{|c|}{ Panel C: By Socio-Economic Status (SES) } \\
\hline Low SES & $\begin{array}{l}-0.07 \\
(0.01)\end{array}$ & $\begin{array}{l}-0.05 \\
(0.01)\end{array}$ & $\begin{array}{l}-2.76 \\
(0.74)\end{array}$ & $\begin{array}{l}-2.07 \\
(0.77)\end{array}$ \\
\hline High SES & $\begin{array}{l}-0.06 \\
(0.01)\end{array}$ & $\begin{array}{l}-0.04 \\
(0.01)\end{array}$ & $\begin{array}{l}-2.40 \\
(0.86)\end{array}$ & $\begin{array}{l}-1.66 \\
(0.93)\end{array}$ \\
\hline
\end{tabular}

Notes: Each cell in the table represents a separate regression. The regressions are estimated in the same manners as those reported in Table 2. Student quality is determined by whether the student's average Magen score was above or below the median. High SES is composed of children whose father was above the median level of education in the sample. The column title reports whether fixed effects are included at the school or student level. Coefficients are reported per 100 units of AQI. Standard errors are heteroskedastic-consistent and are reported below the coefficients in parentheses. 